DOI: $10.37886 /$ ruo.2021.028

\title{
Agilni menedžment
}

\author{
Helena Sekula \\ Fakulteta za organizacijske študije v Novem mestu, Novi trg 5, 8000 Novo mesto, Slovenija \\ helena.sekula@fos-unm.si
}

Anita Ruperčič ${ }^{*}$

Fakulteta za organizacijske študije v Novem mestu, Novi trg 5, 8000 Novo mesto, Slovenija anita.rupercic@fos-unm.si

\begin{abstract}
Povzetek:
Raziskovalno vprašanje (RV): Kaj predstavlja agilnost v delovnem okolju in kateri dejavniki so še posebej pomembni za doseganje agilnosti?

Namen: S tem člankom bi radi opozorili, da ne moremo govoriti o povsem drugačnem menedžmentu ampak o agilnih metodah, kot nadgradnji tradicionalnega menedžmenta, ki mu omogočajo večjo prilagodljivost in ustvarjalnost.
\end{abstract}

Metoda: Pregled strokovne in znanstvene literature.

Rezultati: Agilne metode vodenja so odgovor na marsikateri problem, s katerim se srečuje klasični menedžment. Ljudje z agilno miselnostjo verjamejo, da lahko svoje talente in sposobnosti $\mathrm{z}$ učenjem, vztrajnostjo in strastjo vedno razvijajo in nadgrajujejo. Ljudje $\mathrm{z}$ agilno miselnostjo so zavezani k nenehnemu učenju in obdani z ljudmi, ki jim pomagajo napredovati in postati vedno boljši.

Organizacija: Pomembno je, da podjetja zase najdejo najprimernejšo osrednjo pot med agilnim in standardnim pristopom vodenja. Za spreminjajoče se okoliščine projekta, je vsekakor primernejši agilni menedžment.

Družba: Zelo pomembno je, da so projekti izpeljani učinkovito. Projekti se morajo izpeljati čim hitreje, z najnižjimi stroški in visoko stopnjo kakovosti ter v skladu s cilji projekta. Hkrati morajo projekti prinesti določene koristi, katero je podjetje ugotovilo, da so pomembni in zaradi katerih se je podjetje odločilo za izvedbo projekta.

Originalnost: Učinkovito obvladovanje sprememb je tesno povezano z reševanjem problemov na katere naletimo pri uvajanju sprememb v delovnem okolju. Vedno se srečamo s človeškim faktorjem, ki ga z ustreznim pristopom lahko uporabimo v prid uvedbe sprememb.

Omejitve/nadaljnje raziskovanje: Nadaljnje raziskovanje bi bilo zanimivo razširiti na konkretno organizacijo.

Ključne besede: projekt, menedžment, agilnost, podjetje, spremembe, delovno okolje. 


\section{Uvod}

Kot vemo in se vse bolj zavedamo, živimo $\mathrm{v}$ turbulentnem okolju $\mathrm{z}$ nepredvidljivimi spremembami in potrebami po hitrem odločanju. Zaradi tega se pojavljajo novi pristopi menedžmenta tako projektov kot organizacij. Med njimi je tako imenovani agilni menedžment.

Beseda agilnost izvira iz latinske besede agere, ki pomeni delati (ang. to do). Karakterizira hitrost, lahkotnost, gibčnost, prožnost in spretnost. Beseda agilnost se precej uporablja tudi v športu, kjer pomeni biti eksploziven, prilagodljiv na spremembe smeri, zmanjševanje in povečevanje hitrosti.

Agilno delovno okolje je dinamično, fleksibilno okolje, sposobno hitrega odzivanja na nepričakovane izzive in priložnosti. Deluje na podlagi postopkov in pravil, ki omogočajo hitre spremembe in zagotavljajo stalno konkurenčno prednost. Agilno delovno okolje podpira stalno spremljanje razmer na trgu in zaznavanje potreb strank $\mathrm{z}$ namenom prilagajanja in iskanja novih priložnosti.

Za agilno delovno okolje je značilna organska organiziranost, ki predstavlja timsko delo, visok nivo komuniciranja, majhno stopnjo formalizacije in standardizacije. Organska organiziranost ima ohlapno opredeljena delovna mesta in njihove naloge. Večina aktivnosti se izvaja v obliki projektnega dela z uporabo kombinacije klasičnih in agilnih metod projektnega vodenja. Klasične metode projektnega vodenja predstavljajo ogrodje znotraj katerega lahko z agilnim pristopom povečamo možnosti uspeha.

Ceschi in drugi (2005, str. 26) pravijo, da okrog 90 odstotkov tradicionalnih podjetij, ki uporabljajo tradicionalni pristop menedžmenta, in pozna metode agilnega menedžmenta, čeprav teh metod in tehnik ne uporabljajo. Glavni razlogi za to so površno znanje o agilnem pristopu in metodah, nasprotovanja tem metodam znotraj podjetja in s strani naročnika ter velike geografske razdelitve tima projektov.

Podjetja in organizacije uvajajo spremembe z namenom izboljšav, povišanja učinkovitosti, drugačnega pristopa do strank, boljšega projektnega načina dela, izkoriščanja novih priložnosti oziroma prilagajanja vedno bolj dinamičnem poslovnem okolju - kar pa ni zmeraj enostavno. Sprememba ni enkraten dogodek ampak je proces prehoda organizacije in njenih deležnikov iz trenutnega $\mathrm{v}$ bodoče stanje $\mathrm{z}$ namenom zagotavljanja dolgoročnih pozitivnih učinkov.

Kljub zavedanju, da spremembe potrebujemo, pa to mnogokrat pomeni tudi stres in $\mathrm{v}$ nekaterih primerih začetni upad produktivnost. Zaposleni sprememb v večini primerov ne želijo, saj prinašajo negotovost in nelagodje. Ob spremembah mnogokrat doživljajo odpor in jih zavračajo. Pojavlja se želja po ohranitvi trenutnega stanja, kar pa lahko povzroča nepotrebne konflikte in probleme. 
Marec 2021, leto / year 10, številka / number 1, str. / pp. 57-68.

S tem člankom bi radi opozorili, da ne moremo govoriti o povsem drugačnem menedžmentu ampak o agilnih metodah, kot nadgradnji tradicionalnega menedžmenta, ki mu omogočajo večjo prilagodljivost in ustvarjalnost.

\section{Teoretična izhodišča}

Slovar tujk opredeli pojem agilen kot delaven, marljiv, prizadeven, spreten, gibčen, živahen, vendar bi težko govorili o spretnem in prizadevnem projektnem pristopu, zato menimo, da je smiselno uporabljati kar pojma agilno in agilnost. Metode in tehnike agilnega menedžmenta se $\mathrm{v}$ zadnjih nekaj letih uporabljajo predvsem v IT projektih. Prve metode projektnega managementa so se pojavile že v 80. letih prejšnjega stoletja. Ugotovitve glede agilnega pristopa projektnega menedžmenta (Stare, str. 1-2):

- pojem izhaja iz agilnih metod razvoja informacijskih sistemov (prve so se pojavile že v 80. letih prejšnjega stoletja) in se uporablja predvsem za IT projekte,

- metode poudarjajo vzporedno izvajanje tradicionalno zaporednih faz izvedbe projekta in stalno usklajevanje udeležencev; glede na navedeno so agilne metode primerljive $\mathrm{s}$ sočasnim inženirstvom, ki se je prav tako pojavilo v 80. letih prejšnjega stoletja,

- je bistvo metod sprotno prilagajanje načina izvedbe in podrobno planiranje manjših ciklov izvedbe projekta glede na trenutno dosežene rezultate, spoznanja, ideje ipd.,

- je pomembna usmerjenost $\mathrm{v}$ uporabnika, zato je $\mathrm{v}$ projektni tim vključen tudi predstavnik uporabnikov, ki redno preverja delne rezultate projekta (s čimer se zagotovi večja ustreznost končnega proizvoda željam in zahtevam uporabnikov).

Cilj agilnih metod je doseči višjo kakovost proizvoda in hitreje ter čim bolj zadovoljiti naročnika glede na uporabnost končnega proizvoda. Agilni pristop se fokusira na povečanje vrednosti za naročnika oz. končnega uporabnika in deluje kot pomoč za spreminjajoče se zahteve, vendar ni primeren za vse poslovna področja oziroma vse tipe projekta. Agilni pristop je bolj orientiran na ljudi, kot na plane in procese. Razmerja z naročniki pri agilnih pristopih menedžmenta ni težko obvladovati. Razumevanje želja naročnikov zahteva njihovo neprestano sodelovanje in vključevanje $\mathrm{v}$ projekt in projektni tim. Sodelovanje med naročnikom in projektnim timom vpliva na lažje obvladovanje sprememb zahtev in hitrejše odgovore na spremembe. To pa po mnenju Ceschija in ostalih (2005, str. 21-26) pozitivno vpliva na obvladovanje spremenljivk, kot so obseg, čas in stroški. Beohm in Turner (2005, str. 30-39) pravita, da so agilne prakse manj zahtevne in bolj skladne z naraščanjem potreb za hiter razvoj v IT industriji (razvoj programske opreme) ter obvladljive za sprotne spremembe. Wysocki (2006, str. 274) pravi, da agilni pristop od menedžmenta ne zahteva popolnih dokumentov in da se zahteve odkrivajo sprotno ter se sproti planira. Rothmanova (2007, str. 53) pravi, da se agilni življenjski cikel prične z malo planiranja, ravno toliko, kot je potrebno za začetek in z idejo o produktu, da zadovolji potrebe naročnika.

Ni potrebno, da so plani popolni, morajo pa biti dovolj dobro definirani, da lahko začnemo s projektom - še posebej, če delamo plane za ponovno planiranje. Naročnik poda idejo o produktu in kakšne želje ima, ko se projekt realizira. Tim ne potroši preveč časa za planiranje 
Marec 2021, leto / year 10, številka / number 1, str. / pp. 57-68.

in ima ves čas na razpolago povratne informacije od naročnika, o poteku in procesu dela. Gre za vpogled v status projekta, na stopnjo razvoja, odkrivanja in odpravljanja napak ter timske prevzetost (Rothman 2007, str. 34, 53-55).

Rothmanova (2007, str. 339) pravi, da agilni življenski cikel temelji na povratku informacij (ang. feedback). Agilni življenjski cikel se planira ravno toliko, da se dobi ideja kakšno rešitev bo želel imeti naročnik. Tim ne zapravlja veliko časa za samo planiranje. Namesto tega se usmeri na planiranje skozi ponavljajoče se cikle dejanskega dela. Naročnik projekta usmerja in kontrolira delovanje tima. Obenem pa naročnik dobiva povratne informacije o poteku dela na projektu (Rothman, str. 53-55).

Wysocki (2009, str. 383-420) opredeljuje dva agilna modela življenjskega cikla menedžmenta: ponavljajoč (ang. iterative) in prilagodljiv (ang. adaptive). Ponavljajoč model se uporablja tam, kjer je veliko rešitev znanih. Prilagodljiv model je primeren za projekte, kjer je na začetku manj znanih rešitev in kjer je manj tudi dogovorjenega. Sestavljajo ga številne faze, ki se ponavljajo v ciklih, s povratnimi zankami po končanem vsakem ciklu. Vsak cikel nadaljuje pot na nepopolnosti in z omejenim razumevanjem rešitve. Vsak cikel se uči od predhodnega cikla in planira naslednji cikel v realizacijo rešitve (Wysocki, 2009, str. 404).

Agilni menedžment kot ga opredeljuje Model EFQM (FOŠmeter poslovne odličnosti, 2020):

Odlične organizacije so splošno priznane zaradi svoje sposobnosti prepoznavanja ter uspešnega in učinkovitega odzivanja na priložnosti in nevarnosti:

- uporabljajo mehanizme za prepoznavanje sprememb v svojem zunanjem okolju in jih pretvorijo v potencialne prihodnje scenarije za organizacijo;

- usmerjajo procese, projekte in organizacijske strukture glede na svojo strategijo, s čimer zagotavljajo, da se spremembe lahko izvedejo z ustrezno hitrostjo po celotni verigi vrednosti;

- razvijajo smiselno kombinacijo kazalnikov uspešnosti delovanja procesov in z njimi povezanih končnih rezultatov, ki omogočajo pregled učinkovitosti in uspešnosti ključnih procesov ter njihovega prispevka k strateškim ciljem;

- uporabljajo podatke o trenutni uspešnosti delovanja in sposobnostih svojih procesov, pa tudi ustrezne primerjave $\mathrm{z}$ dosežki najboljših za spodbujanje ustvarjalnosti, inovativnosti in izboljšav;

- uspešno obvladujejo spremembe s strukturiranim vodenjem projektov in ciljno usmerjenim izboljševanjem procesov;

- hitro prilagodijo svojo organizacijsko strukturo za podporo doseganju strateških ciljev;

- vrednotijo in razvijajo tehnološki portfelj, da bi izboljšali agilnost procesov, projektov in organizacije.

Agilni pristop pomeni popolno upoštevanje metodologije, pri čemer učinkovitost pomeni, da se projekt izvede v skladu z merili kot so čas, stroški in kakovost (Stare 2011, str. 28-31). Se pravi, projekt je učinkovito izveden, ko se izvede v najkrajšem času, z najnižjimi stroški in z 
visoko stopnjo kakovosti. Uspešnost pa je širši pojem, o katerem govorimo, ko so koristi večje od vložkov, ko je bil projekt donosen za podjetje in udeležence ter so bili zadovoljni vsi udeleženci.

Agilnost predstavlja spremembo v miselnosti, ki organizaciji omogoča, da se hitreje odzove na zunanje spremembe, hkrati pa spodbuja odpornost, odzivnost in učenje od znotraj. Sposobnost hitrega učenja in prilagajanja sta glavni razliki novih podjetij $\mathrm{v}$ primerjavi $\mathrm{z}$ večjimi, že uveljavljenimi podjetji. Nova podjetja se po navadi osredotočajo na potrebe strank, namesto, da bi jih zadržale le s svojimi notranjimi procesi. Agilnost tako lahko pomeni tudi razvijanje zagonskega mišljenja v večjih organizacijah (Cappelli \& Tavis, 2018).

Štirje dejavniki so še posebej pomembni za doseganje agilnosti. Najprej je pomembna agilna miselnost. To je želja po učenju in pripravljenost na spremembe. Vključuje zanimanje in odpiranje novih priložnosti in novih načinov za izboljšanje. To je osebna kakovost, ki zaposlenim pomaga sprejeti spremembe, izrabiti priložnosti in se bolje prilagajati novim okoliščinam in situacijam. Nadalje je nujno poslanstvo, ki mora poudarjati, da je prilagodljivost ključna na vseh ravneh. Ko se določijo jasni in dokončni cilji, se lahko razvijejo novi postopki in prakse ter dodelijo sredstva za doseganje cilja. Pomembne so tudi nove delovne prakse. Agilno delo vključuje sposobnost hitrega uresničevanja prednostnih nalog in ukrepov ter spreminjanje delovnih praks. Gre za krepitev ljudi, preprečevanje ovir, spoštovanje različnih idej, spodbujanje napak in tolmačenje potreb strank. Zadnji pomemben element je zagotavljanje talentov. Agilnost krepi pomen privabljanja, razvijanja, ohranjanja in spodbujanja pravih zaposlenih. Zahteva zavezo organizacije, $\mathrm{k}$ spodbujanju in podpiranju prilagodljivega vedenja. To lahko vključuje preoblikovanje različnih vidikov, kot so drugačni opisi delovnih mest, načini zaposlovanja, nagrade in novi procesi upravljanja uspešnosti (Hemsleyfraser, 2015).

Skozi raziskavo smo ugotovili, da agilni pristop ni zadosti uveljavljen v praksi. Agilni pristop tudi ni primeren za vse vrste projektov.

Tehnike agilnega menedžmenta se kažejo v planiranju, izvedbi in udeležencih tima. Plan izvedbe se izdela bolj grobo, prav tako končni cilji. Cilji aktivnosti se postavljajo sproti, pred začetkom vsake aktivnosti. Ugotovili smo, da se določene agilne metode in tehnike uporabljajo pri tipih projektov kot so raziskave, aplikativni razvoj izdelkov, projektiranje, gradbeni projekti, reorganizacijski projekti, organizacija raznih dogodkov.

\section{Metoda}

Članek najprej vsebuje proučeno literaturo slovenskih in tujih avtorjev, ki je povezana z našo naslovno tematiko. Pregledali smo razne strokovne knjige, članke in magistrska dela s področja projektnega menedžmenta. Na podlagi proučene literature smo napisali ugotovitve in spoznanja ter te ugotovitve opisali in jih med seboj primerjali. Gre torej za opisno in primerjalno metodologijo dela. 
Marec 2021, leto / year 10, številka / number 1, str. / pp. 57-68.

V raziskovalnem delu članka smo uporabili preglednico ocen FOŠmeter poslovne odličnosti preglednica ocen, ki povzema rezultate samoocenitve matičnih organizacij udeležencev Poletne šole FOŠ »Poslovna odličnost« in sicer 20 za leto 2018 in 49 za leto 2020.

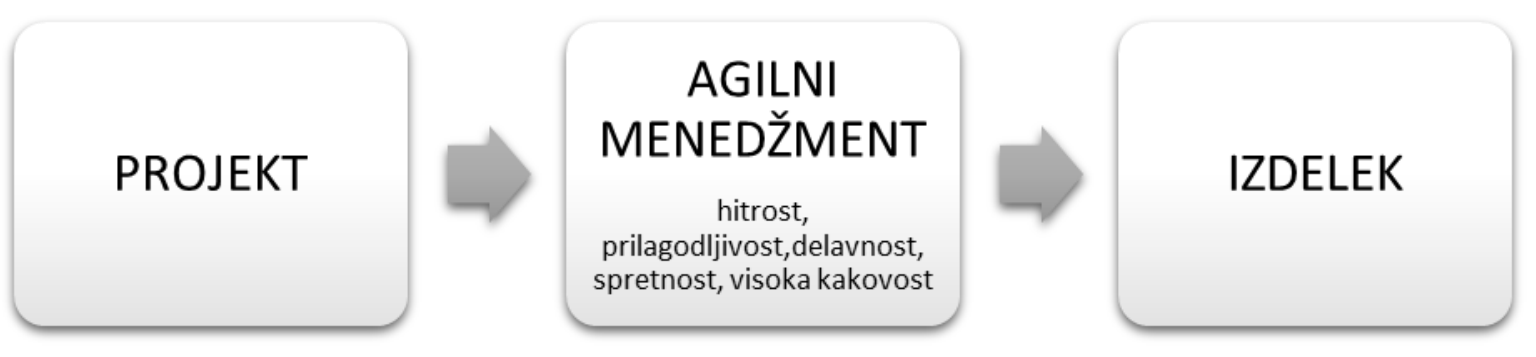

Slika 1. Model raziskave

Tabela 1. Raziskovalno vprašanje s ključnimi besedami

\begin{tabular}{|c|c|c|c|}
\hline \multicolumn{2}{|c|}{ Raziskovalno vprašanje: } & \multicolumn{2}{|c|}{ Ključna beseda: } \\
\hline Slovensko & Angleško & Slovenska & Angleška \\
\hline $\begin{array}{l}\text { Ali izbira agilnega } \\
\text { projektnega } \\
\text { menedžmenta prispeva } \mathrm{k} \\
\text { učinkoviti izvedbi in } \\
\text { uspešnosti projektov? }\end{array}$ & $\begin{array}{l}\text { Does the choice of agile } \\
\text { project management } \\
\text { contribute to the } \\
\text { effective implementation } \\
\text { and success of projects? }\end{array}$ & $\begin{array}{l}\text { "agilnost"+"uspešnost" } \\
\text { "agilnost"+"izvedba" }\end{array}$ & $\begin{array}{l}\text { " agility " + " success " } \\
\text { " agility " + " performance " }\end{array}$ \\
\hline $\begin{array}{l}\text { Ali so tehnike agilnega } \\
\text { projektnega } \\
\text { menedžmenta uporabne } \\
\text { na vseh projektih? }\end{array}$ & $\begin{array}{l}\text { Are agile project } \\
\text { management techniques } \\
\text { applicable to all } \\
\text { projects? }\end{array}$ & "tehnika"+"agilnost" & $\begin{array}{c}\text { " EFQM " } \\
\text { " technique " + " agility " }\end{array}$ \\
\hline
\end{tabular}

Za analizo podatkov smo uporabili datoteko FOŠmeter poslovne odličnosti-preglednica ocen. Izbrani gradnik smo oblikovali v tabelo s povprečnimi vrednostmi ocen po posameznem pod gradniku kot tudi za celoten gradnik in sicer v prvem stolpcu za leto 2018, v drugem za 2020 ter $\mathrm{v}$ tretjem skupno. V vsakem stolpcu smo z zeleno barvo označili najvišjo oceno in z rdečo barvo najnižjo oceno. Ob obarvanju ustreznih ocen smo oblikovali kratek pisni komentar naših ugotovitev (Kos 2020).

Agilne metode vodenja so odgovor na marsikateri problem, s katerim se srečuje klasični menedžment. Ljudje $\mathrm{z}$ agilno miselnostjo verjamejo, da lahko svoje talente in sposobnosti $\mathrm{z}$ učenjem, vztrajnostjo in strastjo vedno razvijajo in nadgrajujejo. Ljudje $\mathrm{z}$ agilno miselnostjo so zavezani k nenehnemu učenju in obdani z ljudmi, ki jim pomagajo napredovati in postati vedno boljši. Zaposleni v agilnih organizacijah so osredotočeni na pridobivanje novih znanj in 
Revija za univerzalno odličnost / Journal of Universal Excellence,

GRADNIKI POSLOVNE ODLIČNOSTI

Marec 2021, leto / year 10, številka / number 1, str. / pp. 57-68.

veščin, njihovi managerji pa se trudijo izboljšati delovno okolje, so bolj odprti do povratnih informacij svojih podrejenih in so jim tudi boljši mentorji (Kos 2020).

\section{Rezultati in razprava}

V tabeli 2 so zbrane ključne ugotovitve, ki jih navajajo različni avtorji, ko opisujejo agilni menedžment.

Tabela 2. Ključne ugotovitve

\begin{tabular}{|c|c|}
\hline Avtor, letnica & Ključne ugotovitve \\
\hline Ceschi in drugi, 2005 & $\begin{array}{l}\text { Okrog } 90 \text { odstotkov podjetij, ki uporabljajo tradicionalni pristop menedžmenta, } \\
\text { ve in pozna metode agilnega menedžmenta, čeprav teh metod in tehnik ne } \\
\text { uporabljajo. }\end{array}$ \\
\hline \multirow[t]{2}{*}{ Stare, 2013} & $\begin{array}{l}\text { Prve metode agilnega managementa so se pojavile že v } \mathbf{8 0} \text {. letih prejšnjega } \\
\text { stoletja. }\end{array}$ \\
\hline & $\begin{array}{l}\text { Metode in tehnike agilnega menedžmenta se v zadnjih nekaj letih uporabljajo } \\
\text { predvsem v IT projektih. }\end{array}$ \\
\hline Beohm in Turner, 2005 & $\begin{array}{l}\text { Agilne prakse so manj zahtevne in bolj skladne z naraščanjem potreb za hiter } \\
\text { razvoj v IT industriji (razvoj programske opreme) ter obvladljive za sprotne } \\
\text { spremembe. }\end{array}$ \\
\hline Wysocki, 2006 & $\begin{array}{l}\text { Agilni pristop menedžmenta ne zahteva popolnih dokumentov in da se zahteve } \\
\text { odkrivajo sprotno ter se sproti planira. }\end{array}$ \\
\hline \multirow[t]{3}{*}{ Rothmanova, 2007} & $\begin{array}{l}\text { Agilni življenjski cikel prične } \mathbf{z} \text { malo planiranja, ravno toliko, kot je potrebno } \\
\text { za začetek in z idejo o produktu, da zadovolji potrebe naročnika. }\end{array}$ \\
\hline & Agilni življenjski cikel temelji na povratku informacij. \\
\hline & Naročnik projekta usmerja in kontrolira delovanje tima. \\
\hline \multirow[t]{3}{*}{ Kos, 2020} & $\begin{array}{l}\text { Ljudje } \mathrm{z} \text { agilno miselnostjo verjamejo, da lahko svoje talente in sposobnosti z } \\
\text { učenjem, vztrajnostjo in strastjo vedno razvijajo in nadgrajujejo. }\end{array}$ \\
\hline & $\begin{array}{l}\text { Ljudje z agilno miselnostjo so zavezani k nenehnemu učenju in obdani z ljudmi, } \\
\text { ki jim pomagajo napredovati in postati vedno boljši. }\end{array}$ \\
\hline & $\begin{array}{l}\text { Zaposleni v agilnih organizacijah so osredotočeni na pridobivanje novih znanj in } \\
\text { veščin, njihovi managerji pa se trudijo izboljšati delovno okolje, so bolj odprti } \\
\text { do povratnih informacij svojih podrejenih in so jim tudi boljši mentorji. }\end{array}$ \\
\hline
\end{tabular}


Marec 2021, leto / year 10, številka / number 1, str. / pp. 57-68.

V tabeli 3 so zbrani rezultati ocenjevanja FOŠmetra poslovne odličnosti. Samoocenitev poslovne odličnosti je bila izvedena po metodologiji, ki jo je razvila Fakulteta za organizacijske študije $v$ Novem mestu in temelji na modelu odličnosti EFQM. FOŠmeter poslovne odličnosti za vsakega od osmih gradnikov odličnosti podaja opise usmeritvenih trditev, pri čemer je bila za potrebe samoocenitve stopnja doseganja stanja vrednotena $\mathrm{v}$ razponu od 0 do 5 kot to predvideva metodologija modela CAF (Commmon Assesement Framework).

Tabela 3: FOŠmeter poslovne odličnosti-preglednica ocen za gradnik Agilni menedžment

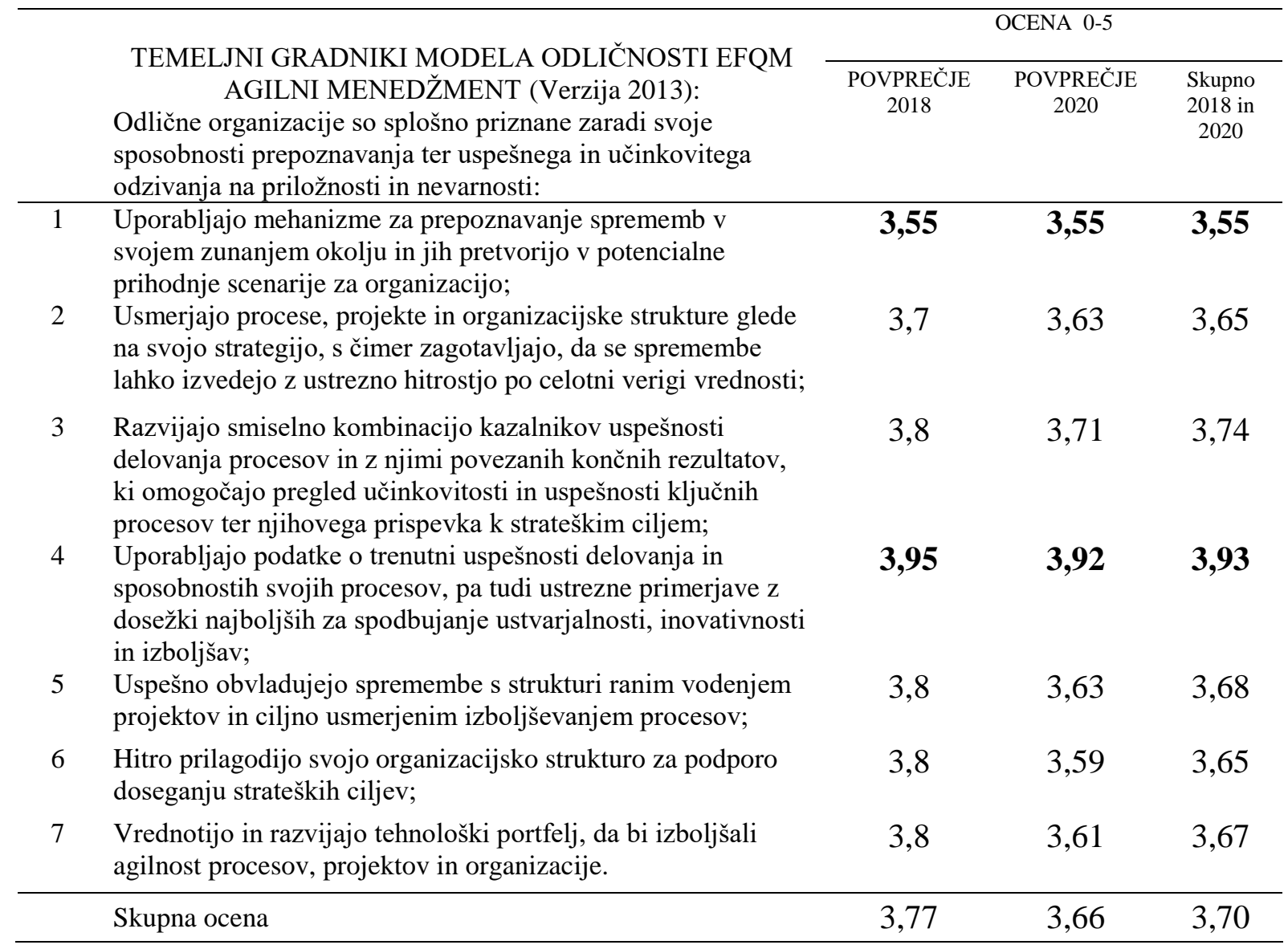

Po analizi gradnika agilnega menedžmenta po FOŠmetru poslovne odličnosti smo prišli do ugotovitev:

- Najvišja ocena iz leta 2018 je bila podana pri temeljnemu gradniku 6,4 uporabljajo podatke o trenutni uspešnosti delovanja in sposobnostih svojih procesov, pa tudi ustrezne primerjave $\mathrm{z}$ dosežki najboljših za spodbujanje ustvarjalnosti, inovativnosti in izboljšav. Pri tem pod gradniku je bila tudi najvišja ocena v letu 2020 in sicer z oceno 3,92 .

- Najnižja ocena iz leta 2018 je bila podana temeljnemu gradniku 6,1 uporabljajo mehanizme za prepoznavanje sprememb v svojem zunanjem okolju in jih pretvorijo $\mathrm{v}$ potencialne prihodnje scenarije za organizacijo. Pri tem pod gradniku je bila tudi najslabša ocena pri letu 2020 in sicer z oceno 3,55. 
- V letu 2020 ni bilo v nobenem pod gradniku napredovanja. V tabeli je razvidno da se je ocena poslabšala $v$ vsakem pod gradniku.

- Največje nazadovanje je bilo pri pod gradniku 6,6 hitro prilagodijo svojo organizacijsko strukturo za podporo doseganju strateških ciljev;

- Skupno najboljše povprečje ki ga je dosegel temeljni gradnik v letu 2018 in 2020 je 6,4 :uporabljajo podatke o trenutni uspešnosti delovanja in sposobnostih svojih procesov, pa tudi ustrezne primerjave $\mathrm{z}$ dosežki najboljših za spodbujanje ustvarjalnosti, inovativnosti in izboljšav;

- Skupno najslabše povprečje, ki ga je dosegel temeljni gradnik v letu 2018 in 2020 je 6,1 uporabljajo mehanizme za prepoznavanje sprememb v svojem zunanjem okolju in jih pretvorijo v potencialne prihodnje scenarije za organizacijo;

- Kot skupno oceno temeljnih gradnikov v primerjavi med leti pa je bilo bolje ocenjeno leto 2018 in $2020 \mathrm{z}$ oceno 3,70 .

- Glede na to, da je bilo leto 2020 leto Covida - 19 se je leto glede na ocene kar dobro obdržalo in ni zabeležilo pretiranega padca.

\section{Zaključek}

V zadnjem času se pri projektih vse bolj uporablja agilni pristop. Ta metoda se je pojavila zaradi vse bolj kompleksnih projektov in njihovega neobvladovanja skozi izvedbo. Kot smo že omenili, se okolje vse bolj spreminja, konkurenca se veča in močno se spreminjajo zahteve naročnikov projektov. Agilna organizacija je tista, ki se hitro prilagaja spremembam ter zna nanje takoj odgovoriti. V prihodnosti pa lahko pričakujemo, da bo pomen agilnosti postajal še večji.

Štirje dejavniki so še posebej pomembni za doseganje agilnosti. Najprej je pomembna agilna miselnost. To je želja po učenju in pripravljenost na spremembe. Vključuje zanimanje in odpiranje novih priložnosti in novih načinov za izboljšanje. To je osebna kakovost, ki zaposlenim pomaga sprejeti spremembe, izrabiti priložnosti in se bolje prilagajati novim okoliščinam in situacijam. Nadalje je nujno poslanstvo, ki mora poudarjati, da je prilagodljivost ključna na vseh ravneh. Ko se določijo jasni in dokončni cilji, se lahko razvijejo novi postopki in prakse ter dodelijo sredstva za doseganje cilja.

Agilno delo vključuje sposobnost hitrega uresničevanja prednostnih nalog in ukrepov ter spreminjanje delovnih praks. Gre za krepitev ljudi, preprečevanje ovir, spoštovanje različnih idej, spodbujanje napak in tolmačenje potreb strank. Zadnji pomemben element je zagotavljanje talentov. Agilnost krepi pomen privabljanja, razvijanja, ohranjanja in spodbujanja pravih zaposlenih. Zahteva zavezo organizacije, $\mathrm{k}$ spodbujanju in podpiranju prilagodljivega vedenja. To lahko vključuje preoblikovanje različnih vidikov, kot so drugačni opisi delovnih mest, načini zaposlovanja, nagrade in novi procesi upravljanja uspešnosti (Hemsleyfraser, 2015). 
Marec 2021, leto / year 10, številka / number 1, str. / pp. 57-68.

Turbulentno okolje od projektov in menedžmenta zahteva hitro prilagajanje. Ravno za to so se pojavili novi pristopi k izvedbi projektov, med katerimi je najbolj prepoznaven agilni pristop. Za agilne metode in tehnike so značilni kratko razvojni cikli, malo napora in preprostost, preglednost, samoorganizacija tima, osredotočenost na ljudi, sodelovanje in komunikacija.

Agilne metode in tehnike dojemajo tveganja kot priložnost. Prav tako so za njih značilni manjši timi, prisotna je velika možnost sprememb zahtev naročnika. Te zahteve upoštevajo nestabilne in hitre spremembe $\mathrm{z}$ uporabo več tehnik in dajejo poudarek na sodelovanju med razvojnim timom in naročnikom projekta. Naročnik tesno sodeluje s timom ali pa je celo del tima. Agilne metode podpirajo tudi hitro dobavo proizvodov naročniku oziroma končnemu uporabniku. Značilnost agilne metode je, da pri razvoju končnega proizvoda ni nujno, da pridemo do popolne rešitve. Dovolj je le, da je naročnik zadovoljen z rezultatom.

Podjetja, ki želijo biti bolj agilna morajo najprej identificirati agilne inkubatorje, ki kasneje predstavljajo gonilo za razširjanje agilnosti na celotno podjetje. Agilni inkubatorji so lahko ekipe, oddelki ali druga podjetja, kjer je podjetje že storilo prve korake k agilnosti.

Inkubatorji podpirajo druge ekipe in oddelke pri izvajanju agilnega načina razmišljanja in delovnih načel. Ta pristop vodi $\mathrm{k}$ nemotenemu procesu preoblikovanja in $\mathrm{v}$ prvi vrsti kratkoročnim izboljšavam. Uporaba prvih zgodb o uspehu služi kot pomembna podporna struktura pri prizadevanjih za širše izvajanje agilnega mišljenja $\mathrm{v}$ organizaciji. Poleg inkubatorjev pa je za razvoj agilne kulture podjetij nujno tudi poudarjanje štirih elementov, ki so med seboj v soodvisnosti. Najprej je pomembna organizacijska kultura, ki mora biti oblikovana na način da spodbuja komunikacijo in razvoj vrednot ne samo od zgoraj navzdol, temveč tudi od spodaj navzgor. Nujno je tudi dobro vodstvo oziroma primerno upravljanje ljudi. Vodje morajo biti pripravljeni prevzeti novo vlogo, kjer se morajo kdaj tudi prilagoditi ter upravljati zaposlene na način, ki ga zadnje čase zaznamuje povečano digitalno sodelovanje. Oblikovati se mora tudi trdna organizacijska struktura in procesi v njej. Prilagajanje organizacijskih struktur in procesov predstavlja predpogoj za trajnostno omogočanje agilnih ukrepov, saj organizacijske strukture in procesi določajo, kako se delo načrtuje in distribuira $\mathrm{v}$ hierarhiji. Agilne organizacije pa morajo biti opremljene tudi $\mathrm{s}$ pravimi orodji in tehnologijami, ki hkrati služijo različnim namenom. Nuditi morajo enostaven dostop do osnovnih agilnih načel, olajšati morajo timsko sodelovanje in s tem omogočiti hitre poslovne reakcije (Denning, 2015). 
Revija za univerzalno odličnost / Journal of Universal Excellence,

GRADNIKI POSLOVNE ODLIČNOSTI

Članek / Article

Marec 2021, leto / year 10, številka / number 1, str. / pp. 57-68.

\section{Reference}

1. Boehm, B., \& Turner, R. (2005). Management challenges to implementing agile processes in traditional development organizations. IEEE Software, 22(5), 30-39

2. Cappelli, P. \& Tavis, A. (2020). HR Goes Agile. Pridobljeno na https://hbr.org/2018/03/the-newrules-of-talent-management\#hr-goes-agile

3. Ceshu, M., Sillitti, A., Succi, G., \& Panfilis, S. (2005). Project management in plan-based ang agile companies. IEEE Software, 22(3), 21-27.

4. Denning, S. (2015). How To Make The Whole Organization Agile. Pridobljeno na https://www.leanagiletraining.com/bw/wp-content/uploads/2014/02/How-To-Make-The-WholeOrganization-Agile-July-2015.pdf

5. Fakulteta za organizacijske študije. (2020, 12. november). FOŠmeter poslovne odličnosti: Preglednica ocen. Pridobljeno na https://moodle.fos-unm.si/course/view.php?id=194.

6. Hemsleyfraser (2018). Becoming an agile organization. Pridobljeno na https://www.hemsleyfraser.com/sites/hemsleyfraser.com/files/resources/AgileOrganisationWP.pdf

7. Kos, B. (2020). Scrum in agilne metode managementa. Pridobljeno na https://www.blazkos.com/scrum-in-agilne-metode-managementa/ $\& \mathrm{~cd}=6 \& \mathrm{hl}=\mathrm{sl} \& \mathrm{ct}=\mathrm{clnk} \& \mathrm{gl}=\mathrm{si}$

8. Rothman, J. (2007). Manage It! Your Guide to Modern Pragmatic Project Management. North Carolina: The Pragmatic Bookshelf.

9. Slovar tujk. Pridobljeno na http://fran.si/iskanje?View=1\&Query=agilen

10. Stare, A. (2013). Agilni prijektni management - inovativen pristop $k$ managementu projektov. Izzivi gospodarskega razvoja 2013 - Inovativni projektni management: zbornik prireditve (str. 139 - 147). Ljubljana: GZS Zbornica osrednjeslovenske regije in Slovensko združenje za projektni management.

11. Wysocki, R. K. (2006). Effective Software Project Management. Indianapolis: Wiley Publishing, Inc.

12. Wysocki, R. K. (2009). Effective Project Management: Traditional, Agile, Extreme (3 rd ed.). Indianapolis: Wiley Publishing, Inc.

Helena Sekula je diplomirala na Fakulteti za organizacijske študije v Novem mestu. Študij nadaljuje na podiplomskem študijskem programu druge stopnje. Zaposlena je $\mathrm{v}$ ugledni farmacevtski industriji $\mathrm{v}$ Novem mestu.

Anita Ruperčič je diplomirala na Fakulteti za organizacijske študije v Novem mestu. Študij nadaljuje na podiplomskem študijskem programu druge stopnje. Zaposlena je $\mathrm{v}$ enem vodilnih podjetji, ki izdeluje pohištvo za vozila za prosti čas. 


\section{Abstract: Managing with Agility}

Research Question (RQ): What does the agility in the work environment present and which actors are of particular importance in achieving agility?

Purpose: With this article, they would like to point out that we do not have to talk about the kind of medical management, but also about agile methods, such as the above-mentioned traditional management, which allow it more adaptability and flexibility.

Method: Review of technical and scientific literature.

Results: Agile management methods are a response to the problem of marshikers, which classifies classical management. People with agile misery believe that their talents and learning skills can be developed and promoted scientifically. People with agile misery are bound to non-formal learning and are endowed with people who help them to progress and become more painful.

Organization: It is important that companies, in turn, find the most appropriate medium between agile and standard management approaches. Against changing the environment of the project, agile management is in any case more appropriate.

Society: It is very important that the projects are implemented effectively. Projects must be successful, with the lowest costs and high levels of quality, and in line with the project's objectives. In short, projects must provide certain benefits that the company has identified as important and, in addition, that the company has decided to carry out the project.

Originality: Effective management of the change is closely linked to the solution of problems on the launcher when introducing the change in the working environment. They shall always be combined with the human factor, which may be applied in an appropriate manner to the relevant approach.

Limitations/Future Research: Further research would be impressively extended to a specific organization.

Keywords: project, management, agility, company, changes, working environment. 